\title{
Commentary
}

\section{The Emergent Role of MicroRNAs in Molecular Diagnostics of Cancer}

\author{
Wayne Tam \\ From the Department of Pathology and Laboratory Medicine, \\ Weill Medical College of Cornell University, New York, New York
}

When lin-4 was discovered in 1993 as a small noncoding RNA that regulates the development of the earthworm Caenorhabditis elegans, ${ }^{1,2}$ it was thought that this RNA was a species-specific peculiarity. Seven years later, another similar small developmentally regulated RNA, let-7, was identified to be evolutionarily conserved, suggesting that this type of RNA molecule has conserved biological functions. ${ }^{3}$ In 2001, multiple novel transcripts of about 22 nucleotides akin to lin-4 and let-7, termed microRNAs (miRNAs), were cloned from worms, flies, and human cells. ${ }^{4-6}$ These studies opened the door for numerous exciting scientific investigations that have important biological and clinical implications.

miRNAs are processed from precursors and in their mature forms, serve as important gene regulators that have the capacity to down-regulate gene expression through translation inhibition and promotion of mRNA degradation mediated by specific target site binding to the $3^{\prime}$-untranslated region of target genes. ${ }^{7}$ According to the most recent version of miRBase (v.11.0), ${ }^{8} 678$ different mature miRNA sequences have been identified in humans to date. Primarily through clinico-pathological studies involving expression analysis of miRNAs in normal and diseased, especially cancerous, human tissues and cells, many of these molecules are emerging as potential markers in molecular diagnostics, particularly in the field of cancer diagnostics. As discussed below, identification of miRNA biomarkers has been facilitated by novel development and refinement of detection methodologies. The work by Szafranska et al, ${ }^{9}$ highlighted in this issue of The Journal of Molecular Diagnostics, details a technical advance that expands the scope of clinical samples amenable for global miRNA analysis.

A unique attribute of miRNAs that renders them potentially useful for the molecular diagnosis of tumors is their tissue and cell lineage specificity. ${ }^{10}$ Many of the miRNAs are highly specific in their expression in specific tissues and cell types, and this specificity is often retained in the corresponding tumor tissues. Identification of cell origin by profiling of miRNAs is more efficient compared with global analysis of mRNAs, because the former is not confounded by such a large pool of irrelevant genes because of the relatively small number of miRNA species. Therefore, miRNAs could facilitate the accurate diagnosis of tumors that are difficult to classify with respect to the tissue origin by conventional means, for example, metastatic cancer of unknown primary origin, ${ }^{11}$ a highly aggressive malignancy that poses diagnostic and management difficulties. ${ }^{12}$ In an initial study by Lu et al, ${ }^{13}$ global microRNA profiling could accurately classify 12 of 17 poorly differentiated carcinomas. The diagnostic accuracy has been further increased with the use of a selected set of miRNAs. Recently, an miRNA classifier consisting of 48 miRNAs generated from 253 samples representing 22 different types of human cancers was found to predict tissue origin with an overall accuracy of $89 \%$ in an independent blinded test set of 83 samples using an algorithm in which one to five specific miRNAs determine the decision at each node of a binary decision tree. ${ }^{14}$ Moreover, the classification accuracy reached $100 \%$ in 6 of the 10 tissue types within the metastatic test set. However, the effectiveness of this set of miRNAs in identifying tissue origin in cases of cancers of unknown primary was not tested in this study. Nevertheless, this methodology compares very favorably with the mRNAbased methods in identifying tissue origins of cancer. Even when only a selected subset of genes is analyzed, the latter method requires a large number of genes (usually hundreds) in the classifier to achieve a similar accuracy as miRNA profiling. ${ }^{15-18}$ Moreover, it uses algorithms that average gene expression levels, which result in loss of diagnostic and potential pathogenetic information. Furthermore, it is more easily confounded by background noise related to natural variations in gene expression. As a result, mRNA-based methods may be less robust. The power of miRNAs in determining the tissue origin of tumors may be further enhanced by incorporating a subset of carefully selected mRNAs to generate a

Accepted for publication June 5, 2008.

This commentary relates to Szafranska et al, J Mol Diagn 2008, 10:415423, published in this issue.

Address reprint requests to Wayne Tam, Department of Pathology \& Laboratory Medicine, Weill Medical College of Cornell University, 525 East 68th St., ST 711A, New York, NY 10021. E-mail: wtam@ med.cornell.edu. 
combined miRNA-mRNA classifier. The rationale behind this lies in the observation that cell-type-specific miRNA signatures correlate with mRNA expression patterns. ${ }^{19}$ Highly expressed mRNAs tend to lack binding sites of highly expressed miRNAs in the same tissues, whereas levels of mRNAs targeted by certain miRNAs tend to be lower in tissues where those miRNAs are present at high levels. Thus, it may be possible to increase the predictive value of the miRNA classifier by simultaneously determining expression of a few selected mRNAs.

Deregulation of miRNAs occurs frequently during tumorigenesis, ${ }^{7}$ making them attractive candidates for molecular detection of malignancy. A subset of miRNAs can often be found up- or down-regulated in tumors compared with the normal tissues in a specific tumor type or more globally in a number of different tumor types. Not only is the identification of these miRNAs critical in the understanding of the pathogenetic role of miRNAs in cancer development, it can also provide a diagnostic methodology for distinguishing tumors from normal tissues of different cell origins. In the current setting of clinical diagnostic practice, where morphological and antigenic evaluation appears to be adequate for accurate diagnostic separation between tumor and normal tissues in the vast majority of biopsies, the utility of miRNA analysis in this arena may not be too apparent. However, the differential expression of miRNAs between tumors and normal tissues may be exploited in the diagnosis of samples where cells are scant or poorly preserved, which may render diagnosis of a malignancy by traditional methods difficult, and in the noninvasive screening for cancer, provided that alterations in specific miRNAs in tumors can be similarly detected in uninvolved body fluids such as peripheral blood.

The latter application is illustrated by the recent discovery that higher levels (about 2.5- to 5-fold) of miR-155, miR-210, and miR-21 can be found in the serum of patients with diffuse large B-cell lymphomas and that higher levels of miR-21 correlates with a longer relapse-free survival. ${ }^{20}$ Circulating nucleic acids have been implicated as biomarkers for various diseases. ${ }^{21}$ This work documents as a proof-of-concept the presence of circulating miRNAs at detectable levels and their utility in cancer diagnosis and prognosis. Because miRNAs are frequently overexpressed in tumors, it is possible that alteration in the profile of circulating miRNAs, which are likely to be derived from tumor cells, is a common occurrence in cancer patients. Thus, detection of miRNAs in serum and other body fluids may serve as a noninvasive means of screening, diagnosing, and prognosing tumors. It may also be used in the detection of occult tumor or minimal residual neoplastic disease, assessment of tumor load, and monitoring of treatment response.

miRNAs may also be useful in subclassifying tumors of a particular tissue origin. Expression of specific miRNAs has been shown to correlate with histological subtypes of certain types of cancer, for example, ductal and lobular breast carcinoma ${ }^{22}$; mucinous and nonmucinous carcinoma of the lung ${ }^{23,24}$; and papillary, follicular, and anaplastic thyroid carcinomas. ${ }^{25-27}$ These miRNAs are likely to play a role in the distinct pathogenetic pathways lead- ing to the different histological subtypes, and may be useful as a diagnostic aid in unusually difficult cases.

There is increasing evidence that miRNAs can be invaluable as a biomarker for patient prognosis. For example, a set of differentially expressed miRNAs were identified in chronic lymphocytic leukemia that can separate it into prognostic categories. ${ }^{28}$ Reduced expression of let-7 and high expression of miR-155 were associated with poor survival in human lung cancers. ${ }^{29}$ High levels of miR-21 are associated with poor survival and poor therapeutic outcome in colon cancer. ${ }^{30}$ In addition, several miRNAs, including miR-10b, miR-126, miR-335, miR-373, and miR-520c were recently found to promote or suppress invasion and metastasis in breast cancer cells. ${ }^{31-33}$ Some of these miRNAs were also shown to correlate with clinical outcome and disease progression in breast cancer. Thus, levels of these miRNAs in primary breast tumors could be useful as predictive biomarkers of their metastatic potential.

The application of miRNAs for molecular diagnostic purposes is critically dependent on the development of methods for their accurate and high-throughput quantification. At present, the most commonly used method for quantitative measurement of miRNAs is the real-time RTPCR. This method is similar to the standard real-time RT-PCR for the detection of mRNA, except that the former makes use of a stem-loop reverse transcription primer for the initiation of cDNA templates. ${ }^{34,35}$ This method is relatively easy to use, highly sensitive and has a broad dynamic range. Another quantitative method is Invader assay, ${ }^{36,37}$ which directly detects specific RNA molecules using an isothermal amplification process with a fluorescent read-out. Since its initial development, the Invader assay for miRNA quantification has undergone modifications (Third Wave Technology, Madison, WI, personal communication). In its current format, it offers comparable sensitivity, specificity, dynamic range, and ease of use as real-time RT-PCR. However, neither of these techniques is optimal for the simultaneous analysis of hundreds of different miRNAs. The method of choice for this type of analysis is global expression profiling, which is mostly performed on glass slide microarrays ${ }^{38,39}$ but also can be performed using bead-based flow cytometry. ${ }^{13}$ The use of locked nucleic acid-modified probes has enhanced the sensitivity and specificity of miRNA microarrays. ${ }^{40}$

Detection of miRNAs can be performed not only with fresh or frozen tissues but also with formalin-fixed, paraffin-embedded (FFPE) samples. miRNA has been shown by RT-PCR to be a superior analyte compared with mRNA when FFPE materials are used because miRNAs are small and therefore less subject to RNA degradation. ${ }^{41}$ FFPE materials have also been used successfully in expression profiling studies of miRNA on different microarray platforms. ${ }^{14,42,43}$ The current study by Szafranska et al in this issue of The JMD systematically compared the use of FFPE and frozen materials and demonstrated that expression profiling of miRNAs can be performed in an accurate and reproducible fashion on FFPE materials using a commercially available, one-color, non-locked nucleic acid-based array platform and optimized RNA 
extraction methods. Their results provide solid evidence for the feasibility of FFPE as a suitable source in miRNA profiling, which would enable a wider collection of clinically annotated patient materials to be studied retrospectively. However, several observations in the study suggest potential pitfalls. Although miRNA expression profiles generated from FFPE materials are highly similar to those derived from frozen materials, there is some loss of signals in the former, particularly when the materials are fixed for a longer duration and when the miRNAs are present in low abundance. Profiling using FFPE materials is also more susceptible to nonspecific signals generated by nonspecific hybridization to degraded products of mRNA. As a result, false negatives and positives can arise more frequently when comparing miRNA expression patterns between two FFPE samples. Fortunately, the detection of the most differentially expressed genes does not appear to be compromised based on a limited comparison. Thus, global comparative expression profiling of FFPE materials may be most suitable for the initial identification of the more differentially expressed and relatively more abundant miRNAs. Reliable identification of less differentially expressed miRNAs of low to medium abundance may require the use of frozen materials, or other quantitative methods if specific miRNAs are known to be involved. Because the concordance of miRNA profiles between FFPE and frozen materials can vary depending on tissue type and block age, a comparison between these two sources for miRNA expression profiling, if feasible, is recommended before embarking a large-scale study on FFPE materials.

Armed with the ability to analyze global miRNA gene expression in FFPE samples, we are in a better position to perform large-scale studies to identify additional miRNAs with potential in cancer diagnostics and to confirm the existing sets of miRNAs as candidates for clinical biomarkers. Besides cancer diagnostics, it is likely that miRNAs will also be useful in molecular diagnostics of other diseases as we begin to elucidate the role of miRNAs in the normal physiology of different organs and their alterations in various disease processes. For example, it is conceivable that circulating miRNAs may be used for risk stratification of chronic diseases like cardiovascular disease or diabetes. Despite the many exciting developments that demonstrate the potential capacity of miRNAs for tumor classification and prognosis, their practical use as biomarkers in a routine clinical setting is still in its infancy. To ascertain and accelerate its advancement beyond the developmental phase, efforts should be made to perform retrospective and prospective studies in global and gene-specific analysis of miRNAs on multiple independent cohorts of patient samples using standardized methodologies. Robust methods for accurate detection of specific or multiple miRNAs using very limited quantities of input RNA need to be developed to enable reproducible and reliable miRNA quantification on small samples, for instance, cytology specimen or laser-capture microdissected tumor cells. To improve accuracy in diagnostic and prognostic classifications and in predicting clinical outcome, miRNA may be evaluated together with a selected set of mRNA and protein markers to develop a "collaborative" classifier. Finally, because miRNAs function as micromanagers in gene regulatory networks, many miRNAs that have been identified as potential markers in neoplasms may have a pathogenetic role instead of being a by-product of the disease states. This immediate pathogenetic relevance makes miRNAs distinct from many other biomarkers. Continued investigations into the biochemical functions of miRNAs through target identification will uncover important mechanistic insights into their potential as biomarkers and therapeutic targets and offer opportunities for discovery of additional biomarkers.

\section{References}

1. Lee RC, Feinbaum RL, Ambros V: The C. elegans heterochronic gene lin-4 encodes small RNAs with antisense complementarity to lin-14. Cell 1993, 75:843-854

2. Wightman B, Ha I, Ruvkun G: Posttranscriptional regulation of the heterochronic gene lin-14 by lin- 4 mediates temporal pattern formation in C. elegans. Cell 1993, 75:855-862

3. Pasquinelli AE, Reinhart BJ, Slack F, Martindale MQ, Kuroda MI, Maller B, Hayward DC, Ball EE, Degnan B, Muller P, Spring J, Srinivasan A, Fishman M, Finnerty J, Corbo J, Levine M, Leahy P, Davidson E, Ruvkun G: Conservation of the sequence and temporal expression of let-7 heterochronic regulatory RNA. Nature 2000 , 408:86-89

4. Lagos-Quintana M, Rauhut R, Lendeckel W, Tuschl T: Identification of novel genes coding for small expressed RNAs. Science 2001, 294:853-858

5. Lau NC, Lim LP, Weinstein EG, Bartel DP: An abundant class of tiny RNAs with probable regulatory roles in Caenorhabditis elegans. Science 2001, 294:858-862

6. Lee RC, Ambros V: An extensive class of small RNAs in Caenorhabditis elegans. Science 2001, 294:862-864

7. Zhang W, Dahlberg JE, Tam W: MicroRNAs in tumorigenesis: a primer. Am J Pathol 2007, 171:728-738

8. Griffiths-Jones S, Saini HK, van Dongen S, Enright AJ: miRBase: tools for microRNA genomics. Nucleic Acids Res 2008, 36:D154-D158

9. Szafranska AE, Davidson T, Shingara J, Doleshal M, Riggenbach JA Morrison CD, Jewell S, Labourier E: Accurate molecular characterization of formalin-fixed, paraffin-embedded tissues by microRNA expression profiling. J Mol Diagn 2008, 10:415-423

10. Landgraf $P$, Rusu M, Sheridan R, Sewer A, Iovino N, Aravin A, Pfeffer S, Rice A, Kamphorst AO, Landthaler M, Lin C, Socci ND, Hermida L, Fulci V, Chiaretti S, Foa R, Schliwka J, Fuchs U, Novosel A, Muller RU, Schermer B, Bissels U, Inman J, Phan Q, Chien M, Weir DB, Choksi R, De Vita G, Frezzetti D, Trompeter HI, Hornung V, Teng G, Hartmann G, Palkovits M, Di Lauro R, Wernet P, Macino G, Rogler CE, Nagle JW, Ju J, Papavasiliou FN, Benzing T, Lichter P, Tam W, Brownstein MJ, Bosio A, Borkhardt A, Russo JJ, Sander C, Zavolan M, Tuschl T: A mammalian microRNA expression atlas based on small RNA library sequencing. Cell 2007, 129:1401-1414

11. Jeffrey SS: Cancer biomarker profiling with microRNAs. Nat Biotechnol 2008, 26:400-401

12. Varadhachary GR, Abbruzzese JL, Lenzi R: Diagnostic strategies for unknown primary cancer. Cancer 2004, 100:1776-1785

13. Lu J, Getz G, Miska EA, Alvarez-Saavedra E, Lamb J, Peck D, Sweet-Cordero A, Ebert BL, Mak RH, Ferrando AA, Downing JR, Jacks T, Horvitz HR, Golub TR: MicroRNA expression profiles classify human cancers. Nature 2005, 435:834-838

14. Rosenfeld N, Aharonov R, Meiri E, Rosenwald S, Spector Y, Zepeniuk M Benjamin H, Shabes N, Tabak S, Levy A, Lebanony D, Goren Y, Silberschein E, Targan N, Ben-Ari A, Gilad S, Sion-Vardy N, Tobar A, Feinmesser M, Kharenko O, Nativ O, Nass D, Perelman M, Yosepovich A, Shalmon B, Polak-Charcon S, Fridman E, Avniel A, Bentwich I, Bentwich Z, Cohen D, Chajut A, Barshack I: MicroRNAs accurately identify cancer tissue origin. Nat Biotechnol 2008, 26:462-469

15. Bloom G, Yang IV, Boulware D, Kwong KY, Coppola D, Eschrich S, 
Quackenbush J, Yeatman TJ: Multi-platform, multi-site, microarraybased human tumor classification. Am J Pathol 2004, 164:9-16

16. Ma XJ, Patel R, Wang X, Salunga R, Murage J, Desai R, Tuggle JT, Wang W, Chu S, Stecker K, Raja R, Robin H, Moore M, Baunoch D, Sgroi D, Erlander M: Molecular classification of human cancers using a 92-gene real-time quantitative polymerase chain reaction assay. Arch Pathol Lab Med 2006, 130:465-473

17. Tothill RW, Kowalczyk A, Rischin D, Bousioutas A, Haviv I, van Laar RK, Waring PM, Zalcberg J, Ward R, Biankin AV, Sutherland RL, Henshall SM, Fong K, Pollack JR, Bowtell DD, Holloway AJ: An expression-based site of origin diagnostic method designed for clinical application to cancer of unknown origin. Cancer Res 2005, 65:4031-4040

18. Shedden KA, Taylor JM, Giordano TJ, Kuick R, Misek DE, Rennert G, Schwartz DR, Gruber SB, Logsdon C, Simeone D, Kardia SL, Greenson JK, Cho KR, Beer DG, Fearon ER, Hanash S: Accurate molecular classification of human cancers based on gene expression using a simple classifier with a pathological tree-based framework. Am J Pathol 2003, 163:1985-1995

19. Sood P, Krek A, Zavolan M, Macino G, Rajewsky N: Cell-type-specific signatures of microRNAs on target mRNA expression. Proc Natl Acad Sci USA 2006, 103:2746-2751

20. Lawrie CH, Gal S, Dunlop HM, Pushkaran B, Liggins AP, Pulford K, Banham AH, Pezzella F, Boultwood J, Wainscoat JS, Hatton CS, Harris AL: Detection of elevated levels of tumour-associated microRNAs in serum of patients with diffuse large B-cell lymphoma. $\mathrm{Br} \mathrm{J}$ Haematol 2008, 141:672-675

21. Tsang JC, Lo YM: Circulating nucleic acids in plasma/serum. Pathology 2007, 39:197-207

22. Iorio MV, Ferracin M, Liu CG, Veronese A, Spizzo R, Sabbioni S, Magri E, Pedriali M, Fabbri M, Campiglio M, Menard S, Palazzo JP, Rosenberg A, Musiani P, Volinia S, Nenci I, Calin GA, Querzoli P, Negrini M, Croce CM: MicroRNA gene expression deregulation in human breast cancer. Cancer Res 2005, 65:7065-7070

23. Garfield D: let-7 microRNA expression and the distinction between nonmucinous and mucinous bronchioloalveolar carcinomas. Lung Cancer 2008, 60:307

24. Yanaihara N, Caplen N, Bowman E, Seike M, Kumamoto K, Yi M, Stephens RM, Okamoto A, Yokota J, Tanaka T, Calin GA, Liu CG, Croce CM, Harris CC: Unique microRNA molecular profiles in lung cancer diagnosis and prognosis. Cancer Cell 2006, 9:189-198

25. He H, Jazdzewski K, Li W, Liyanarachchi S, Nagy R, Volinia S, Calin GA, Liu CG, Franssila K, Suster S, Kloos RT, Croce CM, de la Chapelle A: The role of microRNA genes in papillary thyroid carcinoma. Proc Natl Acad Sci USA 2005, 102:19075-19080

26. Weber F, Teresi RE, Broelsch CE, Frilling A, Eng C: A limited set of human MicroRNA is deregulated in follicular thyroid carcinoma. J Clin Endocrinol Metab 2006, 91:3584-3591

27. Visone R, Pallante $\mathrm{P}$, Vecchione A, Cirombella R, Ferracin M, Ferraro A, Volinia S, Coluzzi S, Leone V, Borbone E, Liu CG, Petrocca F, Troncone G, Calin GA, Scarpa A, Colato C, Tallini G, Santoro M, Croce CM, Fusco A: Specific microRNAs are down-regulated in human thyroid anaplastic carcinomas. Oncogene 2007, 26:7590-7595

28. Calin GA, Ferracin M, Cimmino A, Di Leva G, Shimizu M, Wojcik SE, Iorio MV, Visone R, Sever NI, Fabbri M, Iuliano R, Palumbo T, Pichiorri F, Roldo C, Garzon R, Sevignani C, Rassenti L, Alder H, Volinia S, Liu CG, Kipps TJ, Negrini M, Croce CM: A microRNA signature associ- ated with prognosis and progression in chronic lymphocytic leukemia. N Engl J Med 2005, 353:1793-1801

29. Takamizawa J, Konishi H, Yanagisawa K, Tomida S, Osada H, Endoh H, Harano T, Yatabe Y, Nagino M, Nimura Y, Mitsudomi T, Takahashi $\mathrm{T}$ : Reduced expression of the let-7 microRNAs in human lung cancers in association with shortened postoperative survival. Cancer Res 2004, 64:3753-3756

30. Schetter AJ, Leung SY, Sohn JJ, Zanetti KA, Bowman ED, Yanaihara N, Yuen ST, Chan TL, Kwong DL, Au GK, Liu CG, Calin GA, Croce CM, Harris CC: MicroRNA expression profiles associated with prognosis and therapeutic outcome in colon adenocarcinoma. JAMA 2008, 299:425-436

31. Huang Q, Gumireddy K, Schrier M, le Sage C, Nagel R, Nair S, Egan DA, Li A, Huang G, Klein-Szanto AJ, Gimotty PA, Katsaros D, Coukos G, Zhang L, Pure E, Agami R: The microRNAs miR-373 and miR-520c promote tumour invasion and metastasis. Nat Cell Biol 2008, 10:202-210

32. Ma L, Teruya-Feldstein J, Weinberg RA: Tumour invasion and metastasis initiated by microRNA-10b in breast cancer. Nature 2007, 449:682-688

33. Tavazoie SF, Alarcon C, Oskarsson T, Padua D, Wang Q, Bos PD, Gerald WL, Massague J: Endogenous human microRNAs that suppress breast cancer metastasis. Nature 2008, 451:147-152

34. Chen C, Ridzon DA, Broomer AJ, Zhou Z, Lee DH, Nguyen JT, Barbisin M, Xu NL, Mahuvakar VR, Andersen MR, Lao KQ, Livak KJ, Guegler KJ: Real-time quantification of microRNAs by stem-loop RTPCR. Nucleic Acids Res 2005, 33:e179

35. Raymond CK, Roberts BS, Garrett-Engele P, Lim LP, Johnson JM: Simple, quantitative primer-extension PCR assay for direct monitoring of microRNAs and short-interfering RNAs. Rna 2005, 11:1737-1744

36. Allawi HT, Dahlberg JE, Olson S, Lund E, Olson M, Ma WP, Takova T, Neri BP, Lyamichev VI: Quantitation of microRNAs using a modified Invader assay. RNA 2004, 10:1153-1161

37. Eis PS, Tam W, Sun L, Chadburn A, Li Z, Gomez MF, Lund E, Dahlberg JE: Accumulation of miR-155 and BIC RNA in human B cell lymphomas. Proc Natl Acad Sci USA 2005, 102:3627-3632

38. Nelson PT, Baldwin DA, Scearce LM, Oberholtzer JC, Tobias JW, Mourelatos Z: Microarray-based, high-throughput gene expression profiling of microRNAs. Nat Methods 2004, 1:155-161

39. Thomson JM, Parker J, Perou CM, Hammond SM: A custom microarray platform for analysis of microRNA gene expression. Nat Methods 2004, 1:47-53

40. Castoldi M, Schmidt S, Benes V, Hentze MW, Muckenthaler MU: miChip: an array-based method for microRNA expression profiling using locked nucleic acid capture probes. Nat Protoc 2008, 3:321-329

41. Doleshal M, Magotra AA, Choudhury B, Cannon BD, Labourier E, Szafranska AE: Evaluation and validation of total RNA extraction methods for MicroRNA expression analyses in formalin-fixed, paraffin-embedded tissues. J Mol Diagn 2008, 10:203-211

42. Nelson PT, Baldwin DA, Kloosterman WP, Kauppinen S, Plasterk RH, Mourelatos Z: RAKE and LNA-ISH reveal microRNA expression and localization in archival human brain. RNA 2006, 12:187-191

43. Xi Y, Nakajima G, Gavin E, Morris CG, Kudo K, Hayashi K, Ju J Systematic analysis of microRNA expression of RNA extracted from fresh frozen and formalin-fixed paraffin-embedded samples. RNA 2007, 13:1668-1674 